\title{
THE GOSTS OF CONFLICT: \\ THE IMPACT ON CHINA OF A FUTURE WAR
}

\author{
Edited by \\ Andrew Scobell
}

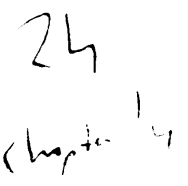

October 2001 